DOI: $10.17951 / \operatorname{lrp} .2020 .39 .1 .181-199$

\author{
JoAnna MajChrzyK-MikuŁa \\ Zakład Historii Oświaty i Wychowania oraz Teorii Kształcenia \\ Instytut Nauk Pedagogicznych, Wydział Nauk Społecznych \\ Uniwersytet Jana Kochanowskiego w Kielcach \\ Filia w Piotrkowie Trybunalskim \\ ORCID - 0000-0003-2920-0447
}

\title{
LUBELSKIE SZKOLNICTWO POWSZECHNE W LATACH 1918-1939 W ŚWIETLE WYMOGÓW SANITARNO-HIGIENICZNYCH
}

\begin{abstract}
Streszczenie: Polska w momencie odzyskania niepodległości stanęła przed wyzwaniem nie tylko zorganizowania od strony formalnej państwa, ale przede wszystkim otoczenia opieką najmłodszych i stworzenia im dogodnych warunków do życia, w tym i do nauki. Wielu higienistów uważało, z czym należy się niewątpliwie zgodzić, że przyczyną wielu schorzeń uczniów był zarówno brak odpowiednich budynków szkolnych spełniających podstawowe wymagania sanitarne, jak i zapewniających bezpieczeństwo i odpowiednią higienę nauczania. Zatem samo wprowadzenie obowiązku szkolnego oraz reform dotyczących programów i struktury szkolnictwa nie dawało podstaw, by sądzić, że został rozwiązany problem polskiej oświaty. Miernikiem jej stanu i warunkiem rozwoju była baza lokalowa oraz budynki szkolne. Niestety brak odpowiednio przygotowanej infrastruktury dało się odczuć w całej Polsce. Analiza źródeł oraz literatury przedmiotu pozwoliła w niniejszym artykule na ukazanie sytuacji szkolnictwa powszechnego na Lubelszczyźnie w niepodległej Polsce. Artykuł traktuje o stanie infrastruktury placówek, a zwłaszcza ich sytuacji materialnej, która miała wpływ na warunki, w jakich uczyła się młodzież. Szczególną uwagę zwrócono na kształtowanie się sieci szkół powszechnych oraz zaprezentowano problemy dotyczące budowy nowych obiektów szkolnych, a zwłaszcza wytycznych w sprawie warunków technicznych i wyposażenia szkół w odpowiednie sprzęty, które zapewnić miały uczniom prawidłowe warunki higieniczne w szkołach.
\end{abstract}

Słowa kluczowe: szkoła, uczeń, higiena, Lubelszczyzna, II Rzeczypospolita

Wojna w znacznym stopniu wpłynęła na pauperyzacje społeczeństwa i ogólną sytuację ekonomiczną na ziemiach polskich. Skalę spustoszeń, jakich dokonała, może 
przybliżyć sprawozdanie z wizji lokalnej powiatu hrubieszowskiego, sporządzone we wrześniu 1915 roku, bezpośrednio po wycofaniu się wojsk rosyjskich, zacytowane przez Bronisława Mikulca, w którym czytamy: „[...] Chałupy opuszczone z oknami bez szyb, odór rozkładających się trupów końskich i jak powiadają nawet ludzkich i biegające po zgliszczach zdziczałe koty - jedyne żywe stworzenia, które tu zostały [...] wszędzie po drogach spotyka się tabory wracających, przeważnie spod Kobrynia wygnańców - załadowane sprzętami domowymi, pierzynami i dziećmi, częstokroć chorymi na cholerę i dyzenterię, wozy ciągnione przez ledwie idące szkapiny, często krowy, a czasem matki i ojców (sprzężaj zarekwirowany), wygnanych przez armię Wielkiej Rosji rodzin [...]"'. Dalszej dewastacji kraju w kolejnych latach dopuściły się wojska niemieckie i austro-węgierskie, nastawione jak wspomniano również na intensywną eksploatację ziem polskich. W ostatecznym rozrachunku na terenach kraju w przededniu odzyskania niepodległości, zniszczonych zostało 55\% mostów, 63\% dworców i 18\% budynków mieszkalnych ${ }^{2}$.

Miało to swój oddźwięk również w szkolnictwie. Co prawda na mocy zarządzenia z 31 października 1915 roku zagwarantowano uczniom szkół publicznych bezpłatne nauczanie, ale nie zapewniono funduszy na utrzymanie i wybudowanie nowych placówek szkolnych. Obowiązek zakładania i utrzymywania publicznych szkół elementarnych ciążył na gminach. Środki materialne, jakimi dysponowały władze lokalne, nie wystarczały na zaspokojenie wszystkich potrzeb, z jakimi borykało się ówczesne szkolnictwo, a dotacje ze strony władz okupacyjnych były znikome. Niewątpliwie wzrosła w tym okresie liczba uczniów, jak również samych szkół Jednak, jak pisał tuż po odzyskaniu niepodległości Kazimierz Konarski, „[...] Dominującym typem szkoły elementarnej, czyli jak ją lud w niektórych okolicach kraju nomen omen nazywa «lamentarnej», jest za czasów okupacji szkoła jednoklasowa czterodziałowa, tj. szkoła, w której jeden nauczyciel w jednej klasie prowadzi równocześnie cztery roczniki dzieci [...]"4.

Ten sam autor podał, że pod koniec 1917 roku w całym Królestwie Polskim przeważały szkoły z jednym nauczycielem, było ich $86 \%$, większość to placówki wiejskie. Lubelszczyzna nie była pod tym względem odosobniona, również i tam

${ }^{1}$ B. Mikulec, 2001, Społeczność Hrubieszowa w okresie I wojny światowej. W: R. Kołodziejczyk (red.), Społeczeństwo polskie $w$ dobie I wojny światowej i wojny polsko-bolszewickiej 1920 roku. Kielce, s. 304.

2 T. Nałęcz, 2006, 1904-1939. W: J. Tazbir (red.), Polska na przestrzeni wieków. Warszawa, s. 549.

${ }^{3}$ W ciągu trzech lat wojny (1914-1917) liczba uczniów przypadających na tysiąc mieszkańców wzrosła z 34 do 60, ale zwiększyła się również liczba uczniów przypadających na jednego nauczyciela z 45 do 59, mimo znacznego powiększenia kadry pedagogicznej z 8969 do 12276. S. Araszkiewicz, 1982, Sytuacja szkolnictwa i oświaty w zaborze rosyjskim w latach 1831-1918. Szkolnictwo elementarne. W: S. Michalski (red.), Dzieje szkolnictwa i oświaty na wsi polskiej do 1918. Warszawa, t. 1, s. 198.

${ }^{4}$ K. Konarski, 1923, Dzieje szkolnictwa w b. Królestwie Kongresowym 1915-1918. Kraków, s. 64. 
polityka władz okupacyjnych sprzyjała rozwojowi sieci szkolnej $j^{5}$. Niestety podobnie jak w całym Królestwie Polskim większość tych placówek miała najniższy stopień organizacji. Prawie we wszystkich powiatach stanowiły one ponad $90 \%$ ogółu szkół.

Niestety rozbudowa szkolnictwa nie była równoznaczna $\mathrm{z}$ jego rozwojem jakościowym. Sytuację szkół elementarnych pogarszał dodatkowo brak własnych budynków. Znaczna ich liczba została zniszczona podczas działań wojennych lub zajęta na potrzeby wojska, co wymuszało na władzach lokalnych wynajmowanie lokali zastępczych, często nieprzystosowanych do pełnienia funkcji placówki oświatowej. Zwłaszcza na terenach, gdzie toczone były walki z Rosjanami i zniszczono doszczętnie zabudowania, w tym i szkoły. Z ogólnej liczby 960 placówek funkcjonujących w 1916 roku w województwie lubelskim aż 67\% prowadziło zajęcia w lokalach wynajętych. Wśród pozostałych, które mieściły się we własnych budynkach, 5\% stanowiły szkoły, które dysponowały zaledwie częścią lokalu niezbędnego do prowadzenia zajęć. W kolejnych latach sytuacja nie uległa zasadniczym zmianom. Opierając się na sprawozdaniach z lat 1917-1918, na które powołuje się Ryszard Kucha, rozbudowa sieci szkół Lubelszczyzny osiągnęła pewną stabilizację, lecz niestety wiele placówek wciąż funkcjonowało w budynkach wynajętych, nieprzystosowanych do prowadzenia zajęć lekcyjnych. Autor jako przykład podaje sytuację powiatu lubelskiego, gdzie na 208 szkół tylko 18 posiadało własny lokal. W samym Lublinie na 24 szkoły 20 pracowało w pomieszczeniach zastępczych ${ }^{6}$.

Przedstawiona sytuacja stanu budynków szkolnych za ziemiach polskich w przededniu odzyskania niepodległości stała się dla przyszłego rządu priorytetową sprawą. Zwłaszcza w sytuacji kiedy, jak pisał jeden z autorów, „Kraj nasz posiada dotąd, $\mathrm{w}$ stosunku do swych potrzeb, znikomo małą liczbę budynków, stawianych na potrzeby szkół i odpowiadającym wszelkim współczesnym wymaganiom. Najgorzej przedstawia się stan rzeczy na ziemiach polskich, będących do niedawna pod zaborem rosyjskim. Ogromna większość szkół wiejskich mieści się

${ }^{5}$ Pod koniec 1915 roku cała Lubelszczyzna została zajęta przez wojska austro-węgierskie i niemieckie. Sytuacja ta wpłynęła na przeobrażenia w szkolnictwie elementarnym. Zostały wprowadzone akty prawne dotyczące oświaty, a zwłaszcza jej organizacji i nadzoru, który miał być sprawowany przez lokalne wojskowe komendy obwodowe. Pierwszy z nich opublikowano jeszcze 7 marca 1915 roku, obowiązywał na ziemiach byłego Królestwa Polskiego okupowanego przez Austro-Węgry i dotyczył właśnie podporządkowania oświaty komendom obwodowym. Tworzenie administracji oświatowej na Lubelszczyźnie zostało zakończone w sierpniu 1916 roku powołaniem Rady Szkolnej Gubernialnej w Lublinie. A. Koprukowniak, 1974, W okresie kształtowania się kapitalizmu 1864-1918. W: T. Mencel (red.), Dzieje Lubelszczyzny. Warszawa, s. 731; B. Wachowska, 1989, Życie społeczno-polityczne i kulturalne w latach pierwszej wojny światowej. W: B. Baranowski (red.), Dzieje Piotrkowa Trybunalskiego. Łódź, s. 368; A. Piasta, 2007, Piotrków Trybunalski podczas pierwszej wojny światowej. Piotrków Trybunalski, s. 139.

${ }^{6}$ R. Kucha, 1998, Z dziejów szkolnictwa elementarnego na Lubelszczyźnie w latach 1914-1918. „Lubelski Rocznik Pedagogiczny”, t. 1, s. 150. 
w zwykłych chatach nie odpowiadających podstawowym warunkom zdrowotnym, ogromna większość szkół w miastach zajmuje wynajęte lokale, tak samo zupełnie nieodpowiednie na użytek szkolny. W samej stolicy państwa - Warszawie znajduje się zaledwie około dziesiątka wzorowych budynków szkolnych"7. Niestety, po odzyskaniu niepodległości, znaczne tereny, w tym Lubelszczyzna, zostały dotknięte kolejnymi wydarzeniami wojennymi, tym razem walkami z Rosjanami w 1920 roku, co jeszcze bardziej pogrążyło sytuację szkolnictwa, również na Lubelszczyźnie, która została dodatkowo zrujnowana.

Dlatego też pierwsze lata rząd polski poświęcił głównie odbudowie szkolnictwa ze zniszczeń wojennych, a przede wszystkim jego polonizacji. Realizacja tych zadań przypadła istniejącemu już na ziemiach Królestwa Polskiego od 3 stycznia 1918 roku Ministerstwu Wyznań Religijnych i Oświecenia Publicznego (MWRiOP), które na mocy ustawy z dnia 4 czerwca 1920 roku o tymczasowym ustroju władz szkolnych zmierzało do zespolenia szkolnictwa na całym obszarze Rzeczypospolitej ${ }^{8}$.

Równolegle z formułowaniem się struktur organizacyjnych szkolnictwa toczyły się wśród pedagogów oraz polityków dyskusje nad kształtem przyszłego systemu oświaty, a zwłaszcza szkoły powszechnej. Skutki długotrwałego funkcjonowania trzech odrębnych systemów szkolnych, jak również polityka oświatowa zaborców wpłynęły bardzo wyraźnie na stan szkolnictwa u progu niepodległości. Zatrważająca była liczba analfabetów, głównie na obszarze byłego Królestwa Polskiego, gdzie w 1918 roku ponad 55\% ludności nie umiało czytać i pisać9. Podobne dane z 1917 roku wykazał spis przeprowadzony podczas okupacji austriackiej na Lubelszczyźnie, gdzie analfabetyzm stwierdzono u $50 \%$ ogółu społeczeństwa ${ }^{10}$. Zatem nie dziwi, że sprawy oświaty wzbudzały tak wielkie zainteresowanie, zwłaszcza w środowiskach pedagogów i polityków ${ }^{11}$.

7 J. Holewiński, 1921, Budynek szkolny. Warszawa, s. 1.

${ }^{8}$ Dziennik Ustaw Rzeczypospolitej Polskiej (dalej: Dz. U. RP )1920, nr 50, poz. 304.

9 Znacznie gorsza sytuacja przedstawiała się w województwach wschodnich, przykładem może być województwo poleskie, gdzie w 1921 roku analfabetyzmem objętych było $71 \%$ społeczeństwa, oczywiście znaczną część, bo aż 78,1\%, stanowiła ludność wiejska. A. Smolarczyk, 2014, Szkolnictwo powszechne i oświata pozaszkolna w województwie poleskim w latach 1919-1939. Warszawa, s. 425.

10 „Ziemia Lubelska”, 1917, nr 132, s. 2.

${ }^{11}$ Jeszcze przed odzyskaniem niepodległości organizowano szereg zjazdów, spotkań i dyskusji na temat oświaty w niepodległej Polsce. Kwestie te poruszane były wielokrotnie podczas zjazdów nauczycielskich. Opracowywano zasady przyszłej organizacji szkolnictwa. Wśród nich znajdował się projekt Ksawerego Praussa, który w dużej mierze został wykorzystany przez niego już jako ministra WRiOP w niepodległej Polsce. K. Prauss, 1917, W sprawie realizacji powszechnego nauczania w Królestwie Polskim. Warszawa, s. 27; Z. Marciniak,1969, Procesy zjednoczeniowe w ruchu nauczycielskim na ziemiach polskich w latach 1915-1919. Warszawa, s. 12; K. Trzebiatowski, dz. cyt., s. 34; S. Mauersberg, 1994, Sejm Nauczycielski (14-17 kwietnia 1919 r.). W: J. Miąso (red.), Studia $z$ dziejów edukacji. Warszawa, s. 240. 
Najważniejszym zadaniem było zapewnienie wszystkim dzieciom będącym $\mathrm{w}$ wieku obowiązku szkolnego możliwości jego realizowania. Za początek państwowej polityki w tym zakresie należy uznać dekret Naczelnika Państwa z 7 lutego 1919 roku wprowadzający w Polsce tzw. obowiązek szkolny, którego realizacja została nałożona na samorządy terytorialne. Jak ważna była to sprawa dla narodu polskiego, świadczy fakt, że stała się ona przedmiotem obrad politycznych, które doprowadziły do wprowadzenia tego zagadnienia do konstytucji z dnia 17 marca 1921 roku. Ustanowiła ona, że nauka w zakresie szkoły powszechnej będzie obowiązkowa, gwarantowała bezpłatne nauczanie w szkołach państwowych i samorządowych ${ }^{12}$.

Mimo wszystko samo wprowadzenie obowiązku szkolnego oraz reform dotyczących programów i struktury szkolnictwa nie dawało podstaw, by sądzić, że został rozwiązany problem polskiej oświaty. Miernikiem jej stanu i warunkiem rozwoju była baza lokalowa oraz budynki szkolne. Niestety brak odpowiednio przygotowanych budynków szkolnych dał się odczuć w całej Polsce, w tym na Lubelszczyźnie ${ }^{13}$.

W procesie budowy polskiego szkolnictwa, a zwłaszcza jego bazy materialnej, bardzo ważną rolę odegrały odpowiednie ustawy i inne akty normatywne. Pierwsze dwa niezwykle istotne dokumenty noszą datę 17 lutego 1922 roku. Są to wspomniane już wcześniej: ustawa o zakładaniu i utrzymywaniu publicznych szkół powszechnych oraz druga o budowie publicznych szkół powszechnych ${ }^{14}$. Zasadniczym postanowieniem tych ustaw było narzucenie obowiązku zakładania i utrzymywania szkół powszechnych przez gminy przy wsparciu finansowym państwa. Władze lokalne były zobowiązane do zapewnienia wszystkim dzieciom objętych obowiązkiem szkolnym, odpowiednich możliwości do nauki, zwłaszcza budynków szkolnych.

Niewątpliwie wydane ustawy i rozporządzenia miały w sposób zasadniczy wpłynąć na polepszenie sytuacji szkół, również i na szkolnictwo województwa lubelskiego. Już od pierwszych dni niepodległości zmagało się ono z wieloma problemami, zwłaszcza bazą materialną ${ }^{15}$. Brakowało wszystkiego, nauczycieli, szkół, podręczników, pomocy naukowych, a nawet podstawowych mebli .

Regulowały one między innymi stopień organizacyjny szkół czy zakres świadczeń w dziedzinie szkolnictwa ponoszonych przez jednostki samorządu terytorial-

${ }_{12}$ Ustawa z dnia 17 marca 1921 r. Konstytucja Rzeczypospolitej Polskiej, Dz. U. RP 1921, nr 44, poz. 267.

${ }_{13}$ M. Falski, 1936, Niedobór izb lekcyjnych $w$ publicznych szkołach powszechnych. „Oświata i Wychowanie", nr 2, s. 34; K. Trzebiatowski,1970, Szkolnictwo powszechne w Polsce w latach w1918-1932. Wrocław, s. 159; W. Garbowska, 1976, Szkolnictwo powszechne w Polsce w latach 1932-1939. Wrocław, s. 148.

${ }^{14}$ Dz. U. RP 1922, nr 18, poz. 144.

15 Stan szkolnictwa w Polsce, 1923, „Nowa Ziemia Lubelska”, nr 13, s. 2. 
nego i państwo. Pierwsza $\mathrm{z}$ nich wprowadzała obwody szkolne, w których to droga dziecka do szkoły nie mogła przekraczać trzech kilometrów oraz reorganizowała dotychczasową sieć szkolną. Stopień organizacyjny szkoły uzależniono od liczby dzieci w wieku szkolnym na danym terenie ${ }^{16}$. Nowe zasady organizacji szkolnictwa powszechnego stawiały miasta w sytuacji uprzywilejowanej, powodując przy tym wyraźne upośledzenie środowisk wiejskich. Natomiast w ustawie o budowie publicznych szkół powszechnych prawodawca nałożył na gminy obowiązek dostarczenia odpowiednich pomieszczeń na izby szkolne i mieszkania dla nauczycieli. Jeżeli gmina takowych nie posiadała, jej zadaniem było przebudować do potrzeb już istniejące budynki lub wydzielić grunty pod nowe zabudowania, a także na boiska i ogrody szkolne. Zgodnie $\mathrm{z}$ art. 3 powyższej ustawy „[...] Obszar gruntu na szkołę wraz z boiskiem i ogrodem szkolnym winien wynosić dla szkół 1-, 2i 3-klasowych co najmniej 0,56 ha, a dla szkół 4-, 5-, 6- i 7-klasowych co najmniej 0,85 ha. Obszar gruntu na budowę domów mieszkalnych dla nauczycieli wraz z podwórzem winien wynosić co najmniej $500 \mathrm{mtr}$. kw. na każde mieszkanie. $\mathrm{Na}$ zmniejszenie obszaru powyższego dla miast, a w wyjątkowych wypadkach dla wsi - może zezwolić, po wysłuchaniu rady szkolnej powiatowej, kurator okręgu szkolnego [...]"17. Jeśli gmina nie posiadała odpowiedniego terenu pod budowę szkoły i nie mogła go nabyć drogą kupna lub też zamiany, to w myśl art. 4 można było dokonać wywłaszczenia gruntu dla celów oświatowych. Nie była to jednak zbyt popularna forma pozyskiwania ziemi na rzecz szkolnictwa, ponieważ dość skomplikowana procedura opóźniała moment rozpoczęcia prac budowlanych. Na realizację powyższych zadań władze państwowe udzielały gminom dotacji w wysokości $50 \%$ kosztów budowy, natomiast na pokrycie pozostałej kwoty mogły się one starać o pożyczki długoterminowe ze Skarbu Państwa ${ }^{18}$. Środki te jednak w rzeczywistości wystarczały tylko na zaspokojenie podstawowych potrzeb. Powodowało to, że jeżeli już słabe pod względem finansowym samorządy decydowały się na budowę, to „[...] Wiele szkół budowanych było sposobem gospodarczym, po najmniejszych kosztach. Niewątpliwie wpływało to na jakość budynków, a z tym

${ }^{16}$ Jeżeli liczba dzieci w wieku szkolnym zamieszkałych w danym obwodzie w przeciągu trzech lat nie przekraczała 60, tworzono szkołę jednoklasową o jednym nauczycielu, przy liczbie od 61 do 100 dzieci - szkoła dwuklasowa o dwóch nauczycielach, przy liczbie od 101 do 150 szkoła trzyklasowa o trzech nauczycielach, od 151 do 200 - szkoła czteroklasowa o czterech nauczycielach, od 201 do 250 - szkoła pięcioklasowa o pięciu nauczycielach, od 251 do 300 - sześcioklasowa o sześciu nauczycielach, jeżeli liczba dzieci przekraczała 300 tworzono szkołę siedmioklasową o siedmiu nauczycielach. W związku z tym na polskiej wsi przeważały szkoły jednoklasowe, co wpływało niekorzystnie na poziom nauczania (K.B. Kochan, 2009, Edukacja elementarna i elementarze porozbiorowe w II Rzeczypospolitej. Kraków, s. 25).

17 Dz. U. RP 1922, nr 18, poz. 144, art. 3.

18 Tamże, art. 10. 
związany komfort nauki dzieci i ich zdrowie [...]"19. W grudniu 1925 roku dokonano zmiany tego zapisu, w wyniku której państwo już nie gwarantowało wsparcia finansowego w wysokości 50\% kosztów budowy, a jedynie udzielało na ten cel pożyczek ${ }^{20}$. Wpłynęło to w znaczący sposób na zahamowanie budownictwa szkolnego.

Gminy, na których ustawowo spoczywał obowiązek zapewnienia środków finansowych na oświatę, zwłaszcza na utrzymanie budynków szkolnych, nie były w stanie tym obowiązkom sprostać. Jak słusznie zauważył wojewoda lubelski „[...] są one za słabe, ażeby same mogły podołać ustawowem obowiązkowi budowy gmachów szkolnych [...]"21. Co prawda wspomniana ustawa o budowie publicznych szkół powszechnych oferowała ze strony państwa pomoc w formie $50 \%$ zasiłków i udzielaniu pożyczek na odbudowę szkolnictwa. Jednak w wielu przypadkach dość skomplikowana procedura zniechęcała samorządy do występowania o kredyty. Należało wypełnić wiele formalności, które często były ponad możliwości intelektualne wielu urzędników, zwłaszcza w samorządach wiejskich ${ }^{22}$. Ponad to w większości były to gminy, które nie mogły sobie pozwolić nawet na częściowe pokrycie inwestycji związanych z budową nowej szkoły. W corocznych budżetach umieszczano pozycję wydatków przeznaczonych na cele szkolne. Jednak były to niewielkie kwoty i trudno było $\mathrm{z}$ nich wygospodarować fundusze na częściową, a tym bardziej całkowitą inwestycję związaną z budową nowych placówek. Sumy przeznaczone na ten cel były w poszczególnych gminach bardzo zróżnicowane, co przekładało się na ilość szkół oddanych do użytku w całym województwie.

Zatem wysiłek państwa i samorządów początkowo ograniczył się do stworzenia minimalnych warunków do nauki w istniejących już szkołach, często o najniższym poziomie organizacyjnym lub wynajmując pomieszczenia od osób prywatnych, co było bardzo kosztowne i nie zawsze na odpowiednim poziomie higieniczno-sanitarnym ${ }^{23}$. W sprawozdaniu nadesłanym do Wydziału Zdrowia Publicznego w Lublinie za rok szkolny 1922/1923 lekarz szkolny opiekujący się lubelskimi szkołami powszechnymi stwierdził, że „[...] 27 istniejących szkół powszechnych w Lublinie własnych budynków nieposiada. Za nielicznymi wyjątkami, mieszczą się one w lokalach wynajętych przeznaczonych na mieszkania

19 J. Majchrzyk-Mikuła, 2013, Higiena szkolna na Lubelszczyźnie w latach 1918-1939 na tle całego kraju, Piotrków Trybunalski, s. 144.

20 Dziennik Urzędowy Ministerstwa Wyznań Religijnych i Oświecenia Publicznego (dalej: Dz. U. MWRiOP) 1926, nr 13, poz. 162, art. 25

${ }^{21}$ Akcja p. wojewody Remiszewskiego w sprawach szkolnictwa, 1927, „Ziemia Lubelska”, nr 15, s. 2.

22 O budowie szkół, 1922, „Ziemia Krasnostawska”, nr 16, (dodatek oświatowy).

${ }^{23}$ Na przykład w powiecie zamojskim 1/3 kwoty przeznaczonej na cele oświatowe przeznaczono na czynsze za wynajęte lokale szkolne. Często właściciele budynków wykorzystując braki lokalowe, specjalnie je podwyższali, by uzyskać większe zyski. Sprawozdanie Inspektora Samorządu za rok 1924, 1925, „Ziemia Zamojska”, nr 9-10, s. 7. 
prywatne lecz nie na szkołę. Wyjątek stanowi szkoła nr 6 i 26, znajdujące się w dawnych lokalach szkolnych, lecz obliczonych na znacznie mniejszą liczbę dzieci. Lokale szkolne znajdujące się przeważnie w domach częstokroć posiadających liczne mieszkania prywatne przyczem niejednokrotnie korzystają ze wspólnej klatki schodowej, ustępów etc. Znacznie rzadziej lokal szkolny znajduje się w oddzielnej oficynie lub też posiada oddzielne wejście z podwórza, które często bywa małe lub bardzo brudne [...]"24. Taki stan niewątpliwie w sposób negatywny rzutował na kwestie zdrowotności i to wieloaspektowo. Nie hamował, a przyczyniał do rozszerzania się chorób zakaźnych, nie wpływał na polepszenie się stanu higienicznego uczniów (choćby banalne umycie rąk stawało się w takich warunkach problemem), a także nie uczył podstawowych zachowań higienicznych, co nie sprzyjało profilaktyce.

Sądzić można, że skoro w mieście wojewódzkim sytuacja szkół nie wyglądała najlepiej, to zapewne bardziej problem ten dotknął palcówki wiejskie. Zjawisko to niejako wymusiło dalsze zmiany mające na celu poprawę tej sytuacji.

W 1922 roku Wydział Budownictwa Szkolnego działający przy MWRiOP opracował i przedstawił normy higieniczne dla budynków szkolnych, a także dla poszczególnych pomieszczeń tych obiektów, według których każde dziecko powinno mieć „[...] zabezpieczoną należytą ilość przestrzeni, powietrza i światła, ażeby szkoła posiadała wszystkie niezbędne pomieszczenia pomocnicze, których liczba przy współczesnych metodach nauczania stale wzrasta: sale do ćwiczeń fizycznych, chemicznych, robót ręcznych, rysunków, sale rekreacyjne, gimnastyczne, śpiewu, urządzenia natryskowe, na zewnątrz zaś budynku szkolnego boisko do gier i zabaw, ogródki szkolne itp. [...]"25. Dokument ten wydany w formie rozporządzenia w sposób bardzo szczegółowy regulował kwestie dotyczące warunków, jakie powinna spełniać prawidłowo zbudowana i urządzona placówka ${ }^{26}$. Ważną kwestię przy budowie szkoły stanowiło jej centralne usytuowanie w danym obwodzie szkolnym. Gwarantowało to w miarę łatwy dostęp do niej wszystkim dzieciom. Według zasad ogólnych projektowania tego typu placówek budynek powinien być parterowy, wolnostojący, umieszczony na działce tak, by docierała do niego duża ilość promieni słonecznych. Wielkościowo przeznaczonym dla nie więcej niż 800 uczniów. Odstępstwa były możliwe jedynie w dużych miastach ze względu na brak odpowiednich

${ }^{24}$ Archiwum Państwowe w Lublinie, Akta Miasta Lublina 1918-1939 (dalej: APL, AmL 1918-1939), syg. 2512, s. 178.

25 S. Kopczyński, 1921, Cele i zadania hjgieny szkolnej, historja higjeny szkolnej w Polsce. W: Higjena szkolna, Warszawa, s. 2.

${ }^{26}$ Rozporządzenie Ministra Wyznań Religijnych i Oświecenia Publicznego $w$ przedmiocie wymiarów i liczby pomieszczeń w budynkach publicznych szkół powszechnych i domach mieszkalnych dla nauczycieli, Dz. U. MWRiOP 1922, nr 12, poz. 112. 
terenów ${ }^{27}$. Nie mniejsze znaczenie miał także rodzaj gleby, na której miał powstać budynek. Grunt suchy, przepuszczalny, pozbawiony organicznych zanieczyszczeń zmniejszał zagrożenie wystąpienia takich chorób, jak dur brzuszny czy czerwonka ${ }^{28}$.

Odpowiednim normom podlegały również pomieszczenia wewnątrz budynków szkolnych. Odstępstwo od nich było możliwe tylko w szczególnych wypadkach za zgodą kuratora Okręgu Szkolnego. Bardzo szczegółowo zostały one opracowane dla pomieszczeń przeznaczonych na zajęcia dydaktyczne. Zgodnie z wytycznymi wymiary izby lekcyjnej były uzależnione od liczby i wieku dzieci, dla których miała być przeznaczona. Instrukcja zawarta w rozporządzeniu MWRiOP zakładała, że powierzchnia jej miała mieścić się w granicach od $42 \mathrm{~m}^{2}$ do $60 \mathrm{~m}^{2}$, zachowując 3,5 m wysokości ${ }^{29}$. Nie bez znaczenia były także długość i szerokość pomieszczenia. Pierwszy wymiar nie mógł przekraczać $9 \mathrm{~m}$. Zignorowanie tej normy mogło mieć wpływ na pogorszenie i tak nienajlepszego stanu zdrowia uczniów, zwłaszcza wzroku. Zbyt duża odległość dziecka siedzącego w ławce od tablicy sprawiała, że wielu z nich miało kłopoty z odczytywaniem informacji na niej zapisanych. Natomiast szerokość izby szkolnej przekraczająca $6 \mathrm{~m}$ przy ówcześnie występującym rodzaju oświetlenia powodowałaby znaczne pogorszenie oświetlenia miejsca pracy ucznia. Według zaleceń ministerialnych dotyczących higieny urządzeń szkolnych w sali lekcyjnej spełniającej powyższe wymagania mogły uczyć się dzieci w liczbie nie większej niż 54, ponieważ tylko wtedy można było zachować minimalną normę $1 \mathrm{~m}^{2}$ podłogi, jaka powinna przypadać ze względów higienicznych na jednego ucznia ${ }^{30}$.

Kolejnym ważnym aspektem z punktu widzenia higienicznego była wysokość izby szkolnej. Zgodnie z wytycznymi MWRiOP wysokość pomieszczenia przeznaczonego na zajęcia lekcyjne powinna wynosić $3,5 \mathrm{~m}$ przy zachowaniu planu normalnego oraz $3,2 \mathrm{~m}$, realizując założenia programu minimalnego budowy szkoły ${ }^{31}$. Także i w tym przypadku szkoły powszechne nie spełniały standardów opracowanych przez ministerstwo.

${ }^{27}$ Budynek parterowy pozwala na większą łączność dzieci z otaczającą ją przyrodą, która wpływa korzystnie na uczącą się dziatwę. F. Eychhorn, 1933, Higjena budynku i urządzeń szkolnych. W: S. Kopczynski (red.), Higjena szkolna. Warszawa, wyd. 2, s. 107-108.

${ }^{28}$ Ziemia nieprzepuszczalna zanieczyszczona dodatkowo odpadkami kuchennymi, a także odchodami pochodzenia zwierzęcego i ludzkiego była idealnym miejscem dla rozwoju drobnoustrojów chorobotwórczych. J. Majchrzyk-Mikuła, Higiena szkolna na Lubelszczyźnie..., s. 145.

${ }^{29}$ Rozporządzenie Ministra Wyznań Religijnych i Oświecenia Publicznego w przedmiocie wymiarów i liczby pomieszczeń w budynkach publicznych szkół powszechnych i domach mieszkalnych nauczycieli, Dz. U. MWRiOP 1922, nr 12, poz. 12.

${ }^{30}$ F. Eychhorn, Higjena budynku..., s. 121-123.

${ }^{31}$ Rozporządzenie Ministra Wyznań Religijnych i Oświecenia Publicznego o częściowej zmianie i uzupełnieniu Rozporządzenia z dnia 5 kwietnia 1922 r. w przedmiocie wymiarów i liczby pomieszczeń w budynkach publicznych szkót powszechnych i domach mieszkalnych dla nauczycieli, Dz. U. MWRiOP 1925, nr 9, poz. 87. 
W pierwszych latach odzyskania niepodległości z analizy danych wynika, że w ciągu pięciu lat 1920/1921-1925/1926 w województwie lubelskim ilość izb lekcyjnych wzrosła ogółem o 90\%. Podobny wskaźnik został osiągnięty zarówno dla sal w budynkach własnych, jak i wynajętych. Przyrost ten nie rozkładał się równomiernie w poszczególnych powiatach. Niewątpliwie na terenach, które najbardziej ucierpiały podczas działań wojennych zarówno w trakcie I wojny światowej, jak i w czasie wojny polsko-rosyjskiej, nastąpił wysoki przyrost, np. w powiecie chełmskim prawie trzykrotnie wzrosła ilość szkół, podobną sytuację odnotowano w bialskim i włodawskim. Pomimo że w powyższej tabeli brakuje danych $\mathrm{z}$ niektórych powiatów $\mathrm{z}$ okresu pierwszych lat niepodległości, to można sądzić, że również i na tych terenach, które poniosły największe straty podczas działań wojennych, nastąpił znaczny przyrost izb szkolnych. W samym powiecie lubelskim już w 1925/1926 przybyło 482 sal lekcyjnych. Jeden z publicystów opisujących sytuację szkół w powiecie lubelskim bardzo trafnie to ujął, pisząc, że „[...] niejedna gmina ma obecnie tyle szkół, ile przed wojną cały powiat, ale szkołom tym brak absolutnie budynków, mieszczą się one w chałupach wynajętych przez włościan, brak im nawet prymitywnych potrzeb i urządzeń. Nie różnią się one niczem od przeciętnej obory [...]"32. Zatem o ile można mówić o wzroście ilościowym sal, na przestrzeni tych kilku lat, to niestety mieściły się one w większości w wynajmowanych pomieszczeniach. Niewiele powiatów mogło pochwalić się własnymi budynkami, jedynie w powiecie hrubieszowskim i janowskim sale własne stanowiły większość. W pozostałych zdecydowanie przeważały szkoły mieszczące się $\mathrm{w}$ wynajmowanych pomieszczenia. W powiecie puławskim i lubelskim ponad $87 \%$ placówek nie posiadało własnych lokali. Należy też w tym kontekście postawić dość trudne pytanie - na ile za brak elementarnej higieny odpowiadali sami pedagodzy, czy im nie przeszkadzała niewietrzona, czy niewybielona nawet skromna izba lekcyjna i inne niedomogi, jakie poniżej opisał jeden z lekarzy? Jaki był ich poziom świadomości? Brak budynków szkolnych zmuszał samorządy do wynajmowania izb, często takich, które nie spełniały żadnych podstawowych wymogów higieniczno-sanitarnych. Zbyt małe izby, średnia województwa lubelskiego w owym czasie to około $30 \mathrm{~m}^{2}$, musiały pomieścić sporą liczbę dzieci. Bywały szkoły, w których na $1 \mathrm{~m}^{2}$ podłogi przypadało czworo, a nawet pięcioro dzieci ${ }^{33}$.

${ }^{32} Z$ dziejów szkolnictwa powszechnego w powiecie Lubelskim, 1925, „Nowa Ziemia Lubelska”, nr 11, s. 2.

${ }^{33} \mathrm{O}$ problemach nurtujących nauczycieli, zwłaszcza o warunkach w jakich przyszło im pracować, dyskutowano na wielu zjazdach, zarówno tych ogólnopolskich, jak i lokalnych. Ze zjazdu inspektorów szkolnych w Lublinie, 1923, „Ziemia Lubelska”, nr 69, s. 3; Ze zjazdu delegatów Ognisk i Oddziałów Zw. Nauczycieli Szkół Powszechnych, 1923, „Ziemia Lubelska”, nr 84, s. 3; Ze Zjazdu Nauczycieli Szkół Powszechnych, 1924, „Nowa Ziemia Lubelska”, nr 142, s. 2. 
Niestety wzrost liczby izb szkolnych nie wskazywał na to, że polepszyły się warunki pracy uczniów i nauczycieli. Nie wszystkie nowo wybudowane szkoły spełniały normy ustawowo narzucone przez MRRiOP, zwłaszcza na terenach województw centralnych i wschodnich. Przeciętna powierzchnia izby lekcyjnej wynosiła 41,5 $\mathrm{m}^{2}$, a poniżej $40 \mathrm{~m}^{2} \mathrm{w}$ szkołach wiejskich ${ }^{34}$. Znacznie mniej niż przewidywały to normy ministerialne, zakładające, że „[...] najbardziej wskazaną ze względów higienicznych i praktycznyczno-szkolnych przy dzisiejszym systemie nauki szkolnej byłaby izba o powierzchni $6 \times 9=54 \mathrm{~m}^{2}[\ldots]^{\prime 35}$. Zaniżanie wymiarów sal często było podyktowane względami finansowymi. Kwoty, jakimi dysponowały samorządy lokalne, były zazwyczaj bardzo skromne i wystarczały jedynie na zaspokojenie minimalnych potrzeb, tak by mogła w miarę funkcjonować placówka szkolna ${ }^{36}$. Ponadto sytuację budżetową wielu gmin pogarszała wzrastająca $\mathrm{z}$ każdym dniem hiperinflacja, przez którą, jak odnotowano w jednym ze sprawozdań Rady Szkolnej w Lubartowie „[...] Ułożenie budżetu było wprost niemożliwe, np. przeznaczona w kwietniu kwota na utrzymanie czystości w szkole przez cały rok, w czerwcu wystarczała na kupno jednej miotły $[. . .]^{\prime 37}$. Podjęcie decyzji o budowie nowej szkoły stanowiło więc ogromne obciążenie dla samorządu lokalnego i niepewność, czy środki finansowe pozwolą na jej ukończenie ${ }^{38}$. W wielu przypadkach starano się realizować to zadanie po kosztach, zapominając często o względach higienicznych i sanitarnych, jakie powinien spełniać budynek szkolny. Znacznie gorzej przedstawiała się sytuacja izb w budynkach wynajmowanych, gdzie przeciętna powierzchnia sali wynosiła około $29 \mathrm{~m}^{2}$, a w województwach centralnych wahała się nawet od 10 do $15 \mathrm{~m}^{2} 39$.

Nie mniej znaczącym czynnikiem, który z punktu widzenia higienistów miał istotny wpływ na funkcjonowanie ludzkiego organizmu, był dostęp do świeżego powietrza. Dlatego też przy projektowaniu i budowie szkół należało zwrócić szczególną uwagę na to, aby na każde dziecko w sali szkolnej przypadała odpowiednia ilość powietrza jak najbardziej zbliżonego swym składem do atmosferycznego, przy zachowaniu właściwej wilgotności i ciepła. Według badań ówczesnych higienistów wzrost poziomu wydychanego dwutlenku węgla w powietrzu izby lekcyjnej powodował wśród uczniów bóle głowy oraz problemy z koncentracją.

${ }_{34}$ Szkoły powszechne Rzeczypospolitej Polskiej w roku szkolnym 1925/26, 1927, Warszawa, s. 28.

35 Tamże, s. 28.

${ }^{36}$ Z posiedzeń Rady Szkolnej Powiatowej, 1921, „Ziemia Krasnostawska”, nr 15, s. 2, (dodatek oświatowy).

${ }^{37}$ M. Łosiowa, 1939, Sprawozdanie z działalności Rady Szkolnej Powiatowej w Lubartowie. W: Samorząd szkolny i szkolnictwo powiatu lubartowskiego w latach 1918-1939. Lubartów, s. 18; M. Ochmański, 1987, Działalność Rady Szkolnej Powiatowej w Lubartowie w latach 1918-1939. „Przegląd Historyczno-Oświatowy”, nr 116, s. 189.

${ }^{38}$ Budowa szkoły powszechnej na Kośminku przerwana, 1923, „Ziemia Lubelska”, nr 231, s. 3.

39 Szkoły powszechne... w roku szkolnym 1925/26, s. 28. 
Wietrzenie sal zalecano także w celu usunięcia zanieczyszczeń mechanicznych i drobnoustrojów chorobotwórczych. Drobne cząsteczki kurzu zawierające ziarnka piasku, opiłki metali, resztki włókien, a także często zarazki gruźlicy, płonicy czy odry wdychane z powietrzem powodowały podrażnienie dróg oddechowych i rozwój chorób zakaźnych. Realizację powyższych zaleceń zapewnić miała prawidłowo funkcjonująca $w$ izbach szkolnych wentylacja, uzyskiwana poprzez zastosowanie pionowych kanałów przewietrzających wyprowadzanych ponad dach budynku szkolnego oraz otwieranie okien ${ }^{40}$. Lokale szkolne województwa lubelskiego, pochodzące w przeważającej większości z wynajmu, nie posiadały wentylacji. Jedyną więc formą wymiany powietrza było otwieranie drzwi i okien w izbie lekcyjnej. Niestety czynność ta wykonywana przez nauczycieli była dość rzadko, zwłaszcza w porze chłodnej, w obawie przed wyziębieniem pomieszczenia. Dodać tutaj należy, że przeciętnie ponad połowa czasu przeznaczonego na zajęcia szkolne przypadała na miesiące zimowe, więc wietrzenie sal lekcyjnych miało charakter incydentalny. Bez wątpienia istotny wpływ na tę sytuację miał sposób ogrzewania pomieszczeń szkolnych. W sprawozdaniach lekarza powiatowego można znaleźć informacje o tym, że piece są zepsute i niedostatecznie ogrzewają pomieszczenia ${ }^{41}$. Zważywszy, że większość szkół w województwie znajdowała się w izbach wynajmowanych w wiejskich chałupach, można przypuszczać, że do ich ogrzewania używano pieców żeliwnych, które nie tylko szybko się rozgrzewały, ale również błyskawicznie stygły, powodując wychłodzenie pomieszczeń. Poważnym problemem ówczesnego szkolnictwa było także zapewnienie odpowiedniej ilości opału niezbędnego do ogrzania pomieszczeń szkolnych ${ }^{42}$.

Kolejną ważną sprawą uregulowaną przez MWRiOP było zaopatrzenie szkół w ustępy. Zgodnie z wytycznymi każda placówka musiała posiadać pomieszczenie sanitarne urządzone zgodnie z wymaganiami techniki i higieny. Głównym założeniem było, by znajdowały się one w budynku szkolnym. Wymagało to jednak istnienia kanalizacji, która w tamtych czasach była rzadkością nawet w miastach. W takim przypadku ubikacje należało urządzać w oddzielnych budynkach, zachowując odpowiednią odległość od szkoły oraz studni ${ }^{43}$. Dlatego też ministerstwo mając na uwadze względy higieniczne, a przede wszystkim sanitarne, zleciło kuratoriom „[...] weirzenie i dopilnowanie, a żeby ze względów higieny i przyzwoitości wszystkie budynki szczególniej po wsiach, oraz te budynki wiejskie,

${ }^{40}$ F. Eychhorn, Higjena budynku..., dz. cyt., s. 85-90.

${ }^{41}$ Archiwum Państwowe w Lublinie, Urząd Wojewódzki Lubelski, Wydział Pracy Opieki i Zdrowia (dalej: APL, UWL, Wydz. POiZ.) syg. 447, s. 17.

${ }^{42}$ APL, UWL. POiZ. syg. 802, s. 32.

${ }^{43}$ Według wytycznych ubikacje powinny być usytuowane w odległości od 10 do $20 \mathrm{~m}$ od budynku szkolnego, F. Eychhorn, Higjena budynku..., dz. cyt., s. 114-115. 
w których znajdują się wynajęte izby szkolne, w jak najprędszym czasie zostały zaopatrzone choćby w prymitywne urządzenia ustępowe (np. drewniane budynki przenośne $z$ dołem, przesypywane ziemią i t.p.) [...]"44. Zgodnie z obowiązującymi normami jedno miejsce ustępowe powinno być przeznaczone na 25 dziewcząt lub 40 chłopców (dodatkowo jeden pisuar na 40 chłopców). Podobnie było w przypadku zaopatrzenie szkół w umywalnie. Zgodnie z wytycznymi MWRiOP zawartymi w okólniku z 1925 roku każda szkoła, w celu wdrożenia u dzieci nawyku dbania o higienę osobistą, powinna być wyposażona w naczynie i przybory niezbędne do mycia rąk. Rozwiązania techniczne powyższych sprzętów były uzależnione od dostępu budynku szkolnego do urządzeń wodociągowo-kanalizacyjnych. W szkołach posiadających wodę przepływową pomieszczenia wyposażone w umywalki, ręczniki oraz mydła miały być projektowane w pobliżu miejsc ustępowych. Natomiast w budynkach szkolnych nieposiadających sieci wodociągowo-kanalizacyjnej okólnik przewidywał stosować „[...] mały zbiornik wody, zaopatrzony w kurek, rynienka blaszana, pochyło ustawiona przy ścianie, z otworami w części bardziej poziomej i duży kubeł do ściekającej wody. Obok na wałku drewnianym (pożądany szklany) ręcznik, zeszyty na końcach, luźno się obracający i mydło, leżące luźno na podstawce. Wszystkie te przybory winny być umieszczone albo w zewnętrznej części pomieszczenia ustępowego, tam, gdzie ustępy są urządzone na zewnątrz budynku szkolnego, albo też, zwłaszcza, gdy chodzi o małe szkółki, winny znajdować się w sieni lub w korytarzu [...]"45. Całkowitymi kosztami zakupu oraz późniejszej eksploatacji tych urządzeń w publicznych szkołach powszechnych w myśl postanowień ministerstwa zostały obciążone gminy. O powadze zapisów zawartych w tym okólniku może świadczyć końcowy fragment dokumentu, w którym ministerstwo zobowiązuje kuratoria do dokonania kontroli realizacji powyższych postanowień w podległych im szkołach. Niestety podobnie jak w wielu innych regionach Polski szkoły województwa lubelskiego nie spełniały tych norm. Stan wyposażenia szkół w naczynia do mycia rąk w województwie lubelskim był fatalny, nie mówiąc już o powszechnym problemie braku ustępów. W 1927 roku ponad 30\% placówek nie posiadało sieci kanalizacyjnej. Wśród wielu sprawozdań niepokojące wyniki o stanie sanitarnym szkół pochodziły przede wszystkim z województw wschodnich, ale też i z centralnych ${ }^{46}$. Niestety wśród nich znajdowała się

${ }^{44}$ Okólnik MWRiOP $w$ sprawie zaopatrzenia szkół w ustępy, Dz. U. MWRiOP 1923 r. nr 6, poz. 45 .

${ }^{45}$ Okólnik MWRiOP do Kuratoriów wszystkich Okręgów Szkolnych, Inspektorów Szkolnych i do ogółu nauczycielstwa $w$ sprawie zaopatrzenia lokali szkolnych $w$ naczynia do mycia rąk, Dz. U. MWRiOP 1925, nr 11, poz. 102.

${ }^{46} \mathrm{Na}$ temat warunków sanitarnych w różnych regionach Polski pisali między innymi: J. Szmurło, 1918, Organizacja opieki higieniczno-lekarskiej w szkołach początkowych m. Warszawy. Postulaty w sprawie opieki higieniczno-lekarskiej w miastach Polski w ogóle. W: J. Bączkiewicz (red.), Pamięt- 
Lubelszczyzna, gdzie dokładne badania na tym terenie zostały przeprowadzone przez jednego z lekarzy szkolnych doktora Kazimierza Dietricha. Spośród wielu nieprawidłowości wykazanych w ankiecie zwrócił on uwagę między innymi na katastrofalny stan pomieszczeń szkolnych, w których „[...] podłogi drewniane, przeważnie zniszczone, ze szparami, i w jednej szkole podłoga gliniana, czyli właściwie niema jej zupełnie. Stan podłóg pod względem czystości pozostawia wiele do życzenia, gdyż przeważnie są one brudne nie do opisania [...]. W większości lokali panuje zimno, bądź wskutek braku opału, bądź też wskutek wadliwej budowy pieców, braku podwójnych okien i złego opatrzenia drzwi [...] Co się tyczy szatni, to nigdzie ich niema i dzieci albo siedzą w klasie w tem samem ubraniu, w którem przyszły z podwórza, albo też ciepłe okrycia składają w klasie na jedną kupę. Ławki we wszystkich szkołach są mało odpowiednie. Spluwaczek i koszów do papieru niema w żadnej szkole, to samo tyczy się umywalni i wody do picia [...]"47. Podobny obraz wielu szkół można było dostrzec w szkolnictwie miejskim. Większość zajęć prowadzono w wynajętych budynkach o bardzo niskim standardzie, wręcz urągającym przepisom sanitarnym. Zdarzały się przypadki, że szkoły zwłaszcza w wynajmowanych lokalach, miały przechodnie sale, często do trzeciej przechodziło się przez dwie poprzednie, co niewątpliwie dezorganizowało naukę. Normą było prowadzenie zajęć na dwie, a nawet trzy zmiany, tak jak to miało miejsce w jednej ze szkół lubelskich, w której nauka trwała nawet do późnych godzin wieczornych ${ }^{48}$. Niestety ze względu na brak funduszy w budżecie miasta do końca lat 30. w Lublinie przybyła tylko jedna szkoła powszechna, z 10 salami lekcyjnymi, w których uczyło się 915 dzieci ${ }^{49}$. Wydatki na oświatę z każdym rokiem ulegały zmniejszaniu, co nie dawało nadziei na polepszenie warunków lokalowych wielu

niki II Zjazdu Higienistów Polskich. Warszawa, s. 176; M. Kozłowski, 1926, Stan sanitarny powiatów województwa wileńskiego w 1926r. W: Pamiętnik Zjazdu IV Higienistów Polskich i V Lekarzy i Działaczy Sanitarnych Miejskich w Wilnie. Wilno; S. Kopczyński, 1929, Zdrowie dziatwy szkót powszechnych w Polsce, Warszawa; M. Ćwirko-Godycki, 1935, Uwagi o stanie sanitarno-higienicznym szkół powszechnych w okręgu szkolnym poznańskim na podstawie sprawozdania za rok 1934/1935. Poznań. Przy czym należy zauważyć, że w okręgu poznańskim ponad 56,5\% szkół, spełniało wszelkie wymogi higieny szkolnej, mimo że wybudowane zostały jeszcze pod koniec XIX.

${ }^{47}$ Doktor Kazimierz Dietrich na polecenie Sejmiku Lubelskiego w roku 1923 rozpoczął badania na temat stanu szkół powszechnych i zdrowia młodzieży w powiecie lubelskim. Wyniki swoich badań opublikował w Spostrzeżeniach, dotyczących stanu szkół powiatu lubelskiego, 1923, „Zdrowie”, nr 12, s. 337.

${ }^{48}$ O stanie szkół powszechnych $w$ Lublinie. Jest to przedruk referatu złożonego na posiedzeniu Rady Miejskiej przez inspektora Zygmunta Podgórskiego, członka Rady Szkolnej w Lublinie, „Ziemia Lubelska”, 1922, nr 154, s. 2; Szkoły powszechne, 1923, „Ziemia Lubelska”, nr 61, s. 4.

${ }^{49}$ Co prawda Magistrat miasta Lublina opracował 3-letni plan budowy szkól, w ramach którego miało powstać sześć gmachów szkolnych. Niestety nie został on zrealizowany, ponieważ ponad połowę budżetu miasta przeznaczano na spłatę kredytu, zaciągniętego w amerykańskiej firmie Ulen and Company na cele komunalne, przez co wiele inwestycji nie mogło być realizowanych 
placówkom. Sytuacja ta mało przyczyniała się więc do poprawy zdrowotności, a zapewne częściej negatywnie rzutowała na te ważne aspekty życia społecznego ${ }^{50}$. W roku szkolnym 1937/1938 ponad 33,6\% szkół Lubelszczyzny posiadało lokale nieodpowiednie do prowadzenia zajęćs ${ }^{11}$. Istniały poważne braki w ich meblowaniu, zaopatrzeniu w sprzęt szkolny oraz pomoce. Brak ławek lub ich nieprzystosowany wymiar do wzrostu dziecka był systematycznie sygnalizowany przez lekarzy w sprawozdaniach poszczególnych powiatów. Nie mówiąc już o nagminnym braku w szkołach miednicy i ręcznika do rąk ${ }^{52}$.

Co prawda wielokrotnie władze wojewódzkie, powołując się na rozporządzenia zarówno MWRiOP, jak i Ministerstwo Opieki i Zdrowia (dalej: MPOiZ), zwracały uwagę organom zajmującym się problemami sanitarno-higienicznymi, by większym nadzorem objąć placówki oświatowe ${ }^{53}$. Niestety nie uporano się do końca $\mathrm{z}$ tym problemem. Tuż przed wybuchem II wojny światowej na Zjeździe Powiatowych Rad Szkolnych jeden z jej uczestników, wyrażając wielkie oburzenie i sprzeciw wobec takiej sytuacji, stwierdził, że „[...] nie można tolerować tego, że przeciętna szkoła wiejska prócz nędznej izby szkolnej nie posiada ani szatni żadnej, ani najszczuplejszego nawet przedsionka, nie mówiąc już o jakiejkolwiek nie sali oczywiście, lecz choćby mizernej izdebce rekreacyjnej, gdzieżby dziecko mogło po przebyciu swojej ciężkiej nieraz drogi odpocząć, rozgrzać się, osuszyć, spożyć posiłek [...]" ${ }^{\prime 2}$. Zapewne nie były to warunki sprzyjające dobrej atmosferze do nauki, a już na pewno nie wpływały pozytywnie na stan zdrowia uczniów.

Mimo tej trudnej sytuacji, w jakiej znalazło się szkolnictwo powszechne Lubelszczyzny w okresie międzywojennym, w zestawieniu ze spuścizną porozbiorową, bilans należy ocenić pozytywnie. $\mathrm{Z}$ analizy dokumentów i literatury wynika wyraźnie, że dążono do poprawy sytuacji i starano się dostosować realne możliwości do olbrzymich potrzeb młodego pokolenia. Wzrosła liczba placówek

w tym też i budowa nowych placówek oświatowych, na które miasto potrzebowało 5,4 mln złotych. J. Marczuk, Oświata i nauka..., s. 193.

${ }^{50}$ F. Popławski, 1928, Poczynania $w$ dziedzinie oświaty i szkolnictwa lubelskiego samorządu terytorialnego i szkolnego w latach 1927 i 1928. W: T. Wolski (red.), Monografia szkolnictwa m. Lublina za czas 1917 do 1927. Lublin, s. 45.

${ }^{51}$ Według sprawozdania z roku 1933/34, w województwie lubelskim, szkoły mieszczące się w nieodpowiednich warunkach stanowiły $34 \%$. Jak widać odsetek ten na przestrzeni czterech następnych lat nie uległ wielkiej zmianie. APL, UWL, Wydz. POiZ, syg. 313, s. 101.

52 APL, AmL 1918-1939, syg. 2653, s. 174.

${ }^{53}$ Powołując się na liczne rozporządzenia i okólniki wydawane przez oba ministerstwa, władze wojewódzkie rozsyłały pisma do władz samorządowych z bardzo szczegółowymi wytycznymi, na co należało zwracać szczególna uwagę i jakie konsekwencje wyciągać w stosunku do osób odpowiedzialnych za naganny stan sanitarno-higieniczny budynków szkolnych. APL, UWL, Wydz. POiZ, syg. 447, s. 35, 39.

${ }^{54}$ Posiedzenie przedstawicieli Powiatowych Rad Szkolnych, 1939, „Oświata i Wychowanie”, z. 1 , s. 74 . 
wybudowanych wysiłkiem społeczeństwa i samorządów. Zachodzące zmiany miały wymiar nie tylko ilościowy, ale także jakościowy. Już w drugiej połowie lat 30. można było zauważyć systematycznie rosnącą liczbę szkół powszechnych o wyższym poziomie organizacyjnym, mieszczących się już w specjalnie do tego przeznaczonych budynkach. Wyjątkowe znaczenia zwłaszcza dla Lubelszczyzny miała aktywna działalność Towarzystwa Popierania Budowy Szkół Powszechnych. Dzięki jego czteroletniej działalności od 1933 do 1937 roku zdołano tam wybudować 206 nowych placówek szkolnych, z których wiele funkcjonuje do dzisiaj.

\section{LITERATURA}

Akcja p. wojewody Remiszewskiego w sprawach szkolnictwa, 1927, „Ziemia Lubelska”, $\mathrm{nr} 15$.

Araszkiewicz S., 1982, Sytuacja szkolnictwa i oświaty w zaborze rosyjskim $w$ latach 1831-1918. Szkolnictwo elementarne. W: S. Michalski (red.), Dzieje szkolnictwa i oświaty na wsi polskiej do 1918. Warszawa, t. 1.

Archiwum Państwowe w Lublinie, Urząd Wojewódzki Lubelski, Wydział Pracy Opieki i Zdrowia syg. 313, 447, 802

Archiwum Państwowe w Lublinie, Akta Miasta Lublina 1918-1939 (dalej: APL, AmL 1918-1939), syg. 2512, 2653

Budowa szkoły powszechnej na Kośminku przerwana, 1923, „Ziemia Lubelska”, nr 231. Ćwirko-Godycki M., 1935, Uwagi o stanie sanitarno-higienicznym szkół powszechnych w okręgu szkolnym poznańskim na podstawie sprawozdania za rok 1934/1935. Poznań.

Dietrich K. Spostrzeżenia, dotyczace stanu szkót powiatu lubelskiego, 1923, „Zdrowie”, nr 12.

Dziennik Urzędowy Ministerstwa Wyznań Religijnych i Oświecenia Publicznego 1926, nr 13, poz. 162, art. 25.

Dziennik Ustaw Rzeczypospolitej Polskiej 1920, nr 50, poz. 304; 1922, nr 18, poz. 144, art. 3

Eychhorn F., 1933, Higjena budynku i urządzeń szkolnych. W: S. Kopczyński (red.), Higjena szkolna. Warszawa, wyd. 2.

Falski M., 1936, Niedobór izb lekcyjnych w publicznych szkołach powszechnych. „Oświata i Wychowanie", $\mathrm{nr} 2$.

Garbowska W., 1976, Szkolnictwo powszechne w Polsce w latach 1932-1939. Wrocław.

Holewiński J., 1921, Budynek szkolny. Warszawa.

Kochan K.B., 2009, Edukacja elementarna i elementarze porozbiorowe w II Rzeczypospolitej. Kraków. 
Konarski K., 1923, Dzieje szkolnictwa w b. Królestwie Kongresowym 1915-1918, Kraków. Kopczyński S., 1921, Cele i zadania hjgieny szkolnej, historja higjeny szkolnej w Polsce, W: Higjena szkolna. Warszawa.

Kopczyński S., 1929, Zdrowie dziatwy szkół powszechnych w Polsce, Warszawa.

Koprukowniak A., 1974, W okresie kształtowania się kapitalizmu 1864-1918. W: T. Mencel (red.), Dzieje Lubelszczyzny. Warszawa.

Kozłowski M., 1926, Stan sanitarny powiatów województwa wileńskiego w 1926r, W: Pamiętnik Zjazdu IV Higienistów Polskich i V Lekarzy i Działaczy Sanitarnych Miejskich $w$ Wilnie. Wilno.

Kucha R., 1998, Z dziejów szkolnictwa elementarnego na Lubelszczyźnie w latach 1914-1918. „Lubelski Rocznik Pedagogiczny”, t. 1.

Łosiowa M., 1939, Sprawozdanie z działalności Rady Szkolnej Powiatowej w Lubartowie. W: Samorząd szkolny i szkolnictwo powiatu lubartowskiego w latach 1918-1939. Lubartów.

Majchrzyk-Mikuła J., 2013, Higiena szkolna na Lubelszczyźnie w latach 1918-1939 na tle całego kraju. Piotrków Trybunalski.

Marciniak Z., 1969, Procesy zjednoczeniowe w ruchu nauczycielskim na ziemiach polskich $w$ latach 1915-1919. Warszawa.

Mauersberg S., 1994, Sejm Nauczycielski (14-17 kwietnia 1919 r.). W: J. Miąso (red.), Studia $z$ dziejów edukacji. Warszawa.

Mikulec B., 2001, Społeczność Hrubieszowa w okresie I wojny światowej. W: R. Kołodziejczyk (red.), Społeczeństwo polskie $w$ dobie I wojny światowej $i$ wojny polsko-bolszewickiej 1920 roku. Kielce.

Nałęcz T., 2006, 1904-1939. W: J. Tazbir (red.), Polska na przestrzeni wieków. Warszawa. O budowie szkót, 1922, „Ziemia Krasnostawska”, nr 16 (dodatek oświatowy).

O stanie szkół powszechnych $w$ Lublinie, 1922, przedruk referatu złożonego na posiedzeniu Rady Miejskiej przez inspektora Zygmunta Podgórskiego, członka Rady Szkolnej w Lublinie. „Ziemia Lubelska”, nr 154.

Ochmański M., 1987, Działalność Rady Szkolnej Powiatowej w Lubartowie w latach 1918-1939. „Przegląd Historyczno-Oświatowy”, nr 116.

Okólnik MWRiOP do Kuratoriów wszystkich Okręgów Szkolnych, Inspektorów Szkolnych i do ogółu nauczycielstwa w sprawie zaopatrzenia lokali szkolnych w naczynia do mycia rąk, Dz. U. MWRiOP 1925, nr 11, poz. 102.

Okólnik MWRiOP w sprawie zaopatrzenia szkół w ustępy, Dz. U. MWRiOP 1923 r. nr 6, poz. 45.

Piasta A., 2007, Piotrków Trybunalski podczas pierwszej wojny światowej. Piotrków Trybunalski.

Popławski F., 1928, Poczynania $w$ dziedzinie oświaty i szkolnictwa lubelskiego samorządu terytorialnego i szkolnego w latach 1927 i 1928. W: T. Wolski (red.), Monografia szkolnictwa m. Lublina za czas 1917 do 1927. Lublin. 
Posiedzenie przedstawicieli Powiatowych Rad Szkolnych, 1939, „Oświata i Wychowanie", z. 1.

Prauss K., 1917, W sprawie realizacji powszechnego nauczania w Królestwie Polskim. Warszawa.

Rozporządzenie Ministra Wyznań Religijnych i Oświecenia Publicznego w przedmiocie wymiarów i liczby pomieszczeń w budynkach publicznych szkół powszechnych i domach mieszkalnych dla nauczycieli, Dz. U. MWRiOP 1922, nr 12, poz. 112.

Rozporządzenie Ministra Wyznań Religijnych i Oświecenia Publicznego w przedmiocie wymiarów i liczby pomieszczeń $w$ budynkach publicznych szkół powszechnych $i$ domach mieszkalnych nauczycieli, Dz. U. MWRiOP 1922, nr 12, poz. 12.

Rozporządzenie Ministra Wyznań Religijnych i Oświecenia Publicznego o częściowej zmianie i uzupełnieniu Rozporządzenia z dnia 5 kwietnia 1922 r. w przedmiocie wymiarów i liczby pomieszczeń w budynkach publicznych szkół powszechnych $i$ domach mieszkalnych dla nauczycieli, Dz. U. MWRiOP 1925, nr 9, poz. 87.

Smolarczyk A., 2014, Szkolnictwo powszechne i oświata pozaszkolna w województwie poleskim w latach 1919-1939. Warszawa.

Sprawozdanie Inspektora Samorzadu za rok 1924, 1925, „Ziemia Zamojska”, nr 9-10. Stan szkolnictwa w Polsce, 1923, „Nowa Ziemia Lubelska”, nr 13.

Szkoły powszechne Rzeczypospolitej Polskiej w roku szkolnym 1925/26, 1927. Warszawa. Szkoły powszechne, 1923, „Ziemia Lubelska”, nr 61.

Szmurło J., 1918, Organizacja opieki higieniczno-lekarskiej w szkołach początkowych m. Warszawy. Postulaty $w$ sprawie opieki higieniczno-lekarskiej w miastach Polski w ogóle. W: J. Bączkiewicz (red.), Pamiętniki II Zjazdu Higienistów Polskich. Warszawa.

Trzebiatowski K., 1970, Szkolnictwo powszechne w Polsce w latach w1918-1932. Wrocław. Wachowska B., 1989, Życie społeczno-polityczne i kulturalne w latach pierwszej wojny światowej. W: B. Baranowski (red.), Dzieje Piotrkowa Trybunalskiego. Łódź.

Z dziejów szkolnictwa powszechnego w powiecie Lubelskim, 1925, „Nowa Ziemia Lubelska", nr 11.

Z posiedzeń Rady Szkolnej Powiatowej, „Ziemia Krasnostawska”, 1921, nr 15 (dodatek oświatowy).

Ze zjazdu delegatów Ognisk i Oddziałów Zw. Nauczycieli Szkół Powszechnych, 1923, „Ziemia Lubelska”, nr 84.

Ze zjazdu inspektorów szkolnych w Lublinie, 1923, „Ziemia Lubelska”, nr 69.

Ze Zjazdu Nauczycieli Szkół Powszechnych, 1924, „Nowa Ziemia Lubelska”, nr 142. 


\title{
HYGIENIC AND SANITARIAN STATE OF SCHOOLS
}

IN THE LUBLIN REGION (1918-1939)

\begin{abstract}
Poland, just before regaining its independence, faced not only the need to integrate formally the country, but most of all it had to take care of the youngest and create for them the right living conditions, including the suitable conditions for education. A number of hygienists claimed that the reason for many illnesses was the lack of proper school buildings fulfilling basic sanitarian conditions, safety and the right hygiene of learning. So the introduction of compulsory education and reforms concerning programs and structure of school system did not allow to think that the problem of Polish education had been solved. The measure of its state and the condition for development was accommodation and school buildings. Unfortunately, the infrastructure was not properly developed and it was visible in the whole Poland. The analysis of sources and source literature allowed to depict in the article the situation of primary school in the Lublin region county in the first years of independence of Poland. The article describes the infrastructure of educational centers, especially their material situation which directly influenced the conditions in which the youth learned. Much attention was paid to the creation of the net of primary schools, especially the data conditioning the technical conditions and equipment which was necessary to provide the pupils with the right hygienic conditions at schools.
\end{abstract}

Keywords: school, a pupil, hygiene, Lublin region, the Second Polish Republic 